\title{
Topsoil translocation in extensively managed arable field margins promotes plant species richness and threatened arable plant species
}

Julien Piqueray ${ }^{1 *}$, Valentin Gilliaux ${ }^{1}$, E.R. Jasper Wubs ${ }^{2,3}$, Grégory Mahy ${ }^{4}$

\begin{abstract}
${ }^{1}$ Natagriwal ASBL, site de Gembloux. Passage des Déportés 2, 5030 Gembloux, Belgium.
${ }^{2}$ Sustainable Agroecosystems Group, Department of Environmental Systems Science, Institute of Agricultural Sciences, ETH Zürich, Zürich, Switzerland.

${ }^{3}$ Department of Terrestrial Ecology, Netherlands Institute of Ecology (NIOO-KNAW), PO Box 50, 6700 AB, Wageningen, The Netherlands.

${ }^{4}$ University of Liege, Gembloux Agro-Bio Tech, Biodiversity and landscape Unit, Passage des Déportés 2, 5030 Gembloux, Belgium.
\end{abstract}

*Author for correspondence: jpiqueray@natagriwal.be

Keywords: arable plant; Belgium; biodiversity; restoration; seed bank; topsoil translocation

Post-print version available:

Open access until March 12, 2020 https://authors.elsevier.com/a/1aRha14Z6teh1b

Else at : https://doi.org/10.1016/j.jenvman.2020.110126 (restricted access) 


\section{Abstract}

Since the 1950s, agriculture has intensified drastically, which has led to a significant biodiversity decline on arable lands. This decline was especially dramatic for segetal plant species, the specialist species of cereal fields. Due to the low population density and poor dispersal abilities of many segetal species, the recovery of species-rich fields may fail even though the environmental conditions are suitable. Therefore, conservation efforts including active restoration measures aimed at recovering segetal vegetation are needed. To this purpose, we propose to alleviate dispersal limitation by means of topsoil translocation from a species-rich donor arable field. At two receiver sites, we tested this technique using two topsoil-spreading densities, i.e. $2.5 \mathrm{~L}_{\text {soil }} / \mathrm{m}^{2}$ and $5 \mathrm{~L}_{\text {soil }} / \mathrm{m}^{2}$ in experimental plots $\left(3 \mathrm{~m}^{2}\right)$. At one receiver site, we tested the impact of topsoil translocation from two different donor sites, while in the other receiver site one donor site was used. We compared plant species diversity and composition of treated plots with control plots as well as with the species composition of the donor sites (field survey) and their seed bank (greenhouse survey). Species richness was increased by topsoil spreading, including richness of threatened species. $33 \%$ and $71 \%$ of the threatened species were successfully translocated respectively at the two receiver sites. At one site, plant cover was also increased, including threatened species cover. Conversely, topsoil spreading did not promote pernicious species that could affect farmer acceptance negatively. Vegetation of translocated plots was more similar in terms of species composition to donor site seed banks than to donor site field survey. The higher spreading density led to increased species richness when seed bank in topsoil had lower density. Our results show that topsoil translocation can be a highly effective method for restoring threatened segetal plant communities in agricultural landscapes. Even when a full plant community was already present (Receiver 1) topsoil transfer led to a doubling in species richness. The seed bank surveys were a good indicator of plant community composition upon topsoil translocation in the field and are therefore advisable to implement in the project-planning phase to evaluate donor site potential. From our results, we recommend to spread soil at an overall rate of 500 seeds $/ \mathrm{m}^{2}$ equivalent. Future studies need to assess the long-term fate of the translocated species as well as the impacts of soil harvests on the donor sites to establish sustainable use levels. 


\section{Introduction}

Since the 1950s, agriculture has intensified drastically, which has led to a significant biodiversity decline on arable land (Stoate et al., 2001). Among the flora associated with arable lands, segetal plant species are those that grow preferentially in cereal fields, and are specialist species of this habitat (RotchésRibalta et al., 2016). Several of them evolved under cropping conditions, leading to regionally-adapted ecotypes and even speciation in a few cases, for example the spelt-mimics Bromus grossus Desf. Ex DC. (Albrecht et al., 2016; Storkey et al., 2012). These plants associated with arable land may play an important role in the functioning of agro-ecosystems and provide several ecological services, pollen and nectar provision (e.g. Cyanus segetum Hill and Papaver spp.), biological pest control (Hicks et al., 2016) and a valuable food resource for farmland birds (Haaland et al., 2011; Marshall et al., 2003; Nicholls and Altieri, 2004, 2013; Wilson et al., 1999). Segetal plants are thus an important part of biodiversity associated with agricultural land, and an integral part of European agricultural history.

Segetal plants have declined during the last century due to agricultural intensification (Storkey et al., 2012), including the increasing use of herbicides and fertilisers, as well as landscape homogenisation that has led to a decrease in field margin density, which acts as local refuge habitat for segetal plants (Albrecht et al., 2016). In addition, deep ploughing (burying of propagules) and efficient seed-cleaning processes have exacerbated segetal species decline (Fried et al., 2009; Piqueray et al., 2018; Storkey et al., 2012). Consequently, segetal species are currently highly threatened throughout Europe (Storkey et al., 2012).

Despite this general decline, new opportunities may be offered for the conservation of segetal plant species within agro-ecosystems. These opportunities come through intentional conservation programs such as dedicated agri-environment schemes (AES) (Lemoine et al., 2018; Meyer et al., 2010), as well as through implementation of less intensive farming practices such as organic cereal production (Lang et al., 2016). In these sites, extensive management conditions may potentially be conducive for the conservation of species-rich arable field (Lemoine et al., 2018). However, in many cases, a history of intensive management has led to impoverished plant species diversity in these fields. Due to the low population density and poor dispersal abilities of many species, the recovery of species-rich arable fields may thus fail even though the environmental conditions have been restored (Bischoff, 2005; Mayer and Albrecht, 2008). Therefore, active species introduction is needed to capitalize on aforementioned opportunities in terms of segetal plant species conservation (Albrecht et al., 2016; Lang et al., 2016). 
Hitherto, sowing seeds of rare segetal plants has been the preferred method for restoring arable field diversity (Albrecht et al., 2016; Lang et al., 2018, 2016). However, it is unlikely that sowing can be implemented for many species as as seeds are difficult to obtain, especially for conservation programs where seeds from local sources are required (Keller et al., 2000). The use of uncleaned crop seed aiming at restoring one of the original dispersal pathways of arable plants was recently proposed (Piqueray et al., 2018). This method nonetheless failed at dispersing rare species, except for the crop mimics such as B. grossus and Bromus secalinus L. . Topsoil translocation may be a suitable alternative method to disperse multiple rather than single species' seeds that are shed at harvest time. Indeed, many arable plants are known to form persistent soil seed banks (Gaba et al., 2017; Saatkamp et al., 2011). Topsoil of species-rich, extensively-managed arable fields, where herbicide use is restricted is, therefore, a potentially-important source of suitable and local seeds. Moreover, topsoil translocation also leads to co-introduction of the plant-associated microbiomes, which can benefit plant establishment (Harris, 2009; Reynolds et al., 2003; Wubs et al., 2016). Topsoil translocation was proposed as a restoration technique for different vegetation types, including Mediterranean grasslands (Buisson et al., 2018), tropical steppes and savannas (Ferreira et al., 2015; Le Stradic et al., 2016), temperate meadows (Vécrin and Muller, 2003; Wubs et al., 2016), heathlands (Wubs et al., 2016) and forests (Hall et al., 2010). However, to our knowledge, it was never applied to the restoration of species-rich arable fields, which represent a very different ecological setting from the more late-successional systems investigated hitherto. Applying topsoil translocation in the context of segetal plant conservation raises several questions.

The first question that arises is about donor site selection, and how to anticipate which donor will lead to the best restoration result at the receiver site. Restoration potential from a given donor site is typically assessed based on floristic surveys. However, the soil seed bank is likely to be the main determinant for the introduced species composition and, therefore, topsoil translocation success. Although a clear relationship between seedbank and above-ground vegetation usually exists, substantial discrepancies can occur (Albrecht, 2005). Thus, there is a need to evaluate if field surveys permit the selection of appropriate donor sites. Furthermore, the amount of soil to be translocated can be a key variable for success. Spreading at too low a density may hamper the establishment of species-rich vegetation. In contrast, too high an amount would lead to an increased seedling density and consequently to increased competition that may disproportionally limit the less competitive species and furthermore be a waste of donor topsoil. Finally, conditions at the receiver sites need to be suitable for successful establishment of segetal plants, and especially, the density of weed populations that will prevent establishment of translocated individuals through competition (Bartha et al., 2014; Cramer et 
al., 2008). In addition, competition between weeds and crop is intensified by fertilization and that may thus impact the restoration success (Albrecht et al., 2016; Rotchés-Ribalta et al., 2016).

In this study, therefore, we aimed at assessing the potential of topsoil translocation as a tool to restore species-rich arable fields, with a particular focus on threatened segetal species. We tested: (i) the topsoil density to be spread at receiver site, (ii) the effect of different donor sites, their above-ground vegetation and their soil seed bank, (iii) the conditions at receiver site, including fertilization. As some arable plant species may contribute to severe yield loss, conservation programs should pay special attention to prevent the proliferation of such pernicious weeds (Wagner et al., 2017). We, therefore, took account of these undesirable species in our assessment. We hypothesized that (i) a higher topsoil density to be spread at receiver sites promotes restoration success, as more propagules are introduced. Next, we predicted that (ii) the plant species composition in receiver sites can be steered by using donor sites that differ in their plant species composition (sensu Wubs et al., 2016), because of different plant propagule inputs and resulting reciprocal plant-soil microbe interactions causing alternative successional trajectories (Wubs et al., 2019). We predicted that (iii) a seed bank analysis of the donor sites is a better predictor of species composition at the receiver sites compared to aboveground vegetation surveys, since propagules have to survive in soil and subsequently germinate upon topsoil translocation, selective forces that are mimicked in a seed bank analysis. Finally, (iv) we predicted that restoration success will be larger under more infertile receiver site conditions, because plant-plant competition is expected to reduce establishment success of newly introduced species.

\section{Methods}

\section{Study sites}

Topsoil translocation experiments took place at two arable fields, henceforth called 'receiver sites', located in Wallonia, Southern Belgium (Fig. 1). Both receiver sites were in nature reserves aimed at the conservation of arable plants. Parts of the field margin were under Agri-Environment Scheme (AES) for this purpose (Lemoine et al., 2018), and the rest of the fields was under organic farming management. The AES consists of a typically 12-m-wide strip at the field margin, and targets spontaneous segetal plants. Cereals have to be cropped in at least three years over the five-year contract. Pesticide spraying and fertilizing are prohibited. Harvesting must be implemented when the grain is ripe (no immature cereal cropping) to allow the completion of segetal plant life-cycles, including seed shedding. Some of the prescriptions in organic agriculture, including the absence of spraying, are similar to those of the AES. Other prescriptions may be different, such as fertilization (forbidden in AES, while organic fertilization is permitted in organic agriculture). 


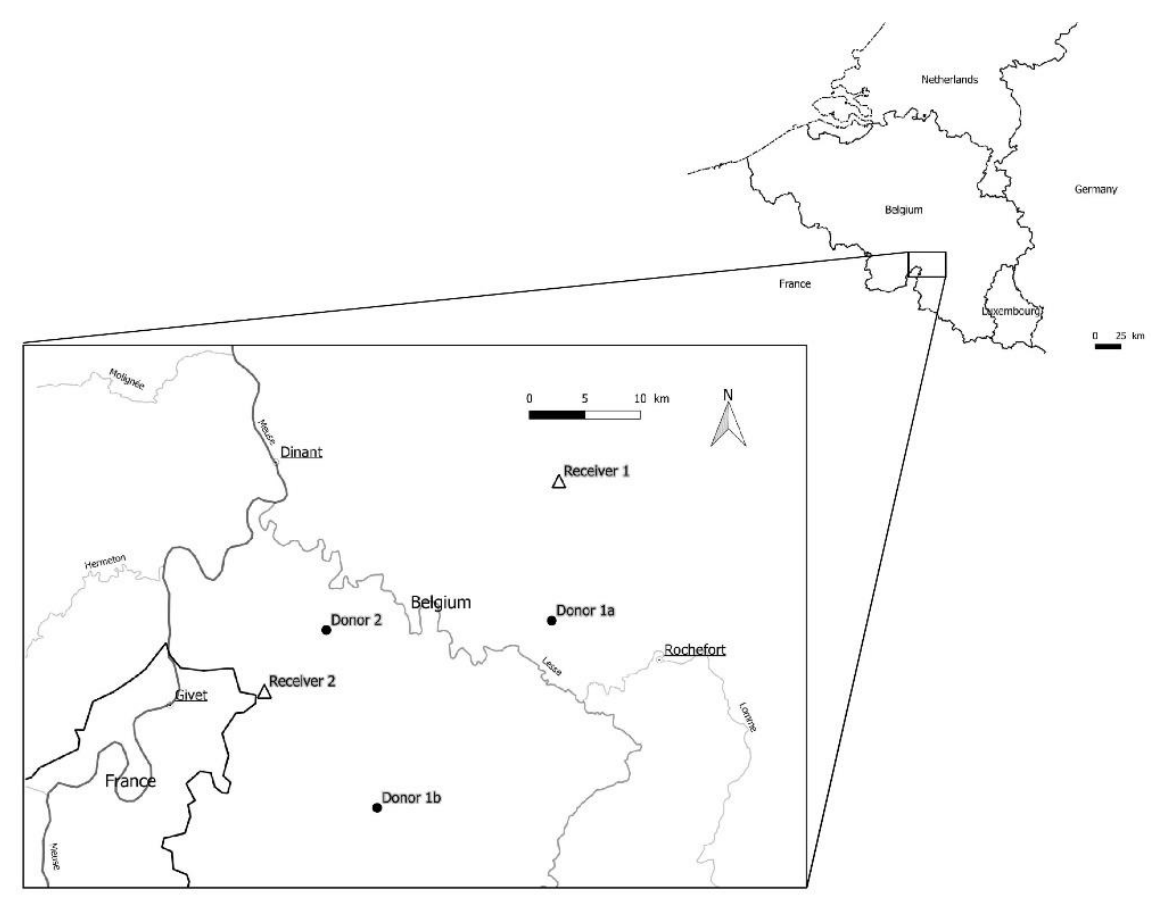

Fig. 1: Localization of receiver (empty triangles) and donor (black dots) sites. White dots with underlined labels are main cities. Grey lines are main rivers (darker lines are more important rivers). Topsoil transfers occurred from Donor sites $1 \mathrm{a}$ and $1 \mathrm{~b}$ to Receiver site 1 (experiment 1) and from Donor site 2 to Receiver site 2 (experiment 2).

At the first receiver site (Receiver 1), we conducted an experiment using two donor sites (Donor 1a and Donor 1b; Table 1). Topsoil was collected in 2017 when Donor 1a was planted with oilseed rape (Brassica napus L.) crop and Donor $1 \mathrm{~b}$ was planted with oat (Avena sativa L.). Field surveys at these sites were conducted in 2017 and 2016, respectively. The surveys showed that these two donor sites differed substantially in plant species composition. Donor 1a is particularly species-rich, with 81 species recorded, but Donor $1 \mathrm{~b}$ harboured particular threatened species that were not found in Donor $1 \mathrm{a}$, such as Silene noctiflora L. and Valerianella rimosa Bast. . Both donors were, therefore, included so as to increase the overall realized species richness in Receiver 1. In the second experiment (Receiver 2), we used a single donor site (Donor 2 ) at $5 \mathrm{~km}$ distance. It had an oat (A. sativa) crop in the year of topsoil collection. It was surveyed in 2014 and sheltered 40 species, of which 7 were threatened segetal species. Receiver 1 has deeper soil, with lower stone load, than its two donor sites (Bock et al., 2008) suggesting it to be more fertile, while low drainage at Receiver 2 made this site the less fertile. Vegetation surveys at donor sites were made according to the AES monitoring protocol, which consists of slowly walking along all field edges approximately $2 \mathrm{~m}$ inside the field margin, recording all observed species. The monitored areas were $1060 \mathrm{~m}^{2}, 500 \mathrm{~m}^{2}$ and $230 \mathrm{~m}^{2}$ respectively for Donor $1 \mathrm{a}$, Donor $1 \mathrm{~b}$ and Donor 2. 


\begin{tabular}{lccc}
\hline Site & Location & Distance to receiver [km] & Coordinates \\
\hline $\begin{array}{c}\text { Experiment 1 } \\
\text { Receiver 1 }\end{array}$ & Ychippe & $/$ & $50^{\circ} 15^{\prime} 02^{\prime \prime} \mathrm{N}, 5^{\circ} 08^{\prime} 27^{\prime \prime} \mathrm{E}$, alt: $302 \mathrm{~m}$ \\
$\begin{array}{c}\text { Donor 1a } \\
\text { Donor 1b }\end{array}$ & Briquemont & 8 & $50^{\circ} 10^{\prime} 43^{\prime \prime} \mathrm{N}, 5^{\circ} 08^{\prime} 04^{\prime \prime} \mathrm{E}$, alt: $181 \mathrm{~m}$ \\
& Tanville & 21 & $50^{\circ} 04^{\prime} 52^{\prime \prime} \mathrm{N}, 4^{\circ} 59^{\prime} 38^{\prime \prime} \mathrm{E}$, alt: $280 \mathrm{~m}$ \\
Experiment 2 & & \\
Receiver 2 & Feschaux & $/$ & $50^{\circ} 08^{\prime} 31^{\prime \prime} \mathrm{N}, 4^{\circ} 54^{\prime} 07^{\prime \prime} \mathrm{E}$, alt: $199 \mathrm{~m}$ \\
Donor 2 & Mesnil-Eglise & 5 & $50^{\circ} 10^{\prime} 24^{\prime \prime} \mathrm{N}, 4^{\circ} 57^{\prime} 08^{\prime \prime} \mathrm{E}$, alt: $240 \mathrm{~m}$ \\
\hline
\end{tabular}

Table 1: Site description. Name is the site name that is used throughout the document.

\section{Topsoil collection}

We collected the topsoil (0-20 cm deep) from the three donor sites in August 2017, i.e. after harvest but before ploughing. At each site, topsoil was collected using a $20 \mathrm{~cm}$-width spade along the boundaries of the field $(20 \mathrm{~cm} * 20 \mathrm{~cm} * 20 \mathrm{~cm}$ sods every $2-5 \mathrm{~m}), 2$ to $10 \mathrm{~m}$ inside the field. The soil was sieved over a $1 \mathrm{~cm}$ mesh to remove larger stones and roots. The soil was homogenized and packaged in plastic bags in 2.5liter doses and stored in an unheated greenhouse until spread in the field in the autumn of 2017. Very little germination occurred in the bags during storage. The total amount of topsoil needed for experiment was $150 \mathrm{~L}$ for Donor 1a and $1 \mathrm{~b}$, and $250 \mathrm{~L}$ for Donor 2.

\section{Field experiments}

The first experiment consisted in comparing the two donor sites (Donor 1a and Donor 1b) at Receiver 1, both with two topsoil spreading densities $\left(2.5\right.$ litres $/ \mathrm{m}^{2}$ and 5 litres $/ \mathrm{m}^{2}$, respectively low and high density). This resulted in four treatments to which an untreated control was added (without topsoil application). The experiment was setup as a randomized block design with five replicate blocks. The blocks were placed along the field margin and each block had five plots $(3 \times 1 \mathrm{~m})$ placed perpendicular to the field margin. The experiment was set up on the $7^{\text {th }}$ November 2017, the day after spelt-sowing (Triticum spelta L.) at a standard sowing density of $200 \mathrm{~kg} / \mathrm{ha}$. Topsoil was hand-spread homogeneously in each treatment and then tamped using a plank.

The second experiment was conducted at the Receiver 2 site, using topsoil from Donor 2 . The same densities of $2.5 \mathrm{~L} / \mathrm{m}^{2}$ and $5 \mathrm{~L} / \mathrm{m}^{2}$, respectively low and high density, were tested, as well as an untreated control. This experiment was also implemented as a randomized block experiment (plots $3 \times 1 \mathrm{~m}$ ), with five blocks along the northern and five blocks along the southern border of the field. The northern border was under AES management for arable plant conservation since 2006 and has not received any fertilization since that date (Lemoine et al., 2018). This margin will be referred to as 'AES-strip'. In 
contrast, the southern margin was cultivated under organic farming and received organic fertilization. We will refer to it as 'Standard field margin'. The experiment was set up on $4^{\text {th }}$ October 2017, the day after the sowing of a mixture of cereals, i.e. oat (A. sativa) and triticale ( $\times$ Triticosecale Wittmack), and legumes, i.e. forage pea (Pisum sativum L. subsp. arvense) and common vetch (Vicia sativa L. subsp. sativa). Topsoil was hand-spread homogeneously and then tamped using a plank.

We conducted floristic surveys of the experiments on $16^{\text {th }}$ and $17^{\text {th }}$ June 2018 (Receiver 1 ) and $29^{\text {th }}$ and $31^{\text {st }}$ May 2018 (Receiver 2). For each plot, the list of occurring species was compiled and their abundance was evaluated using a modified version of the Braun-Blanquet scale (i.e. 5: 76-100\%; 4: 5175\%; 3: 25-50\%; 2b: 15-25\%; 2a: 5-15\%; 1: 1-5\%; +: 0-1\%). To evaluate success of topsoil translocation, the following indices were calculated:

- Species richness, i.e. the number of species $/ 3 \mathrm{~m}^{2}$ plots. The total species richness was divided into segetal and threatened species richness as well.

- Species cover, i.e. the sum of abundance-class medians of the species and total, segetal, threatened and pernicious species cover were tallied from these data.

Segetal status was established based on the habitat descriptions in Lambinon et al. (2004), and by comparison with neighbouring countries' segetal species lists (Cambecèdes et al., 2012; Hofmeister and Garve, 1998). Conservation status was taken from the Walloon red list for plant species (SaintenoySimon et al., 2006). Pernicious weeds were discriminated according to Storkey and Westbury (2007). Nomenclature follows Lambinon et al. (2004).

\section{Topsoill seed bank survey}

The seed bank study was established in December 2017 in an unheated greenhouse. We filled containers $(54 \mathrm{~cm} \times 40 \mathrm{~cm} \times 6.5 \mathrm{~cm})$ with potting soil with a $2 \mathrm{~cm}$ layer of clay balls underneath for drainage and moisture retention. Topsoil from the donor sites was then poured onto the potting soil surface at a $2.5 \mathrm{~L}_{\text {soil }} / \mathrm{m}^{2}$ equivalent rate. For each donor site ten containers were used. Five control containers were also established without any soil addition to detect external contamination. Species that occurred in these control containers (i.e. Salix caprea L. (624 seedlings), Taraxacum sp.(37 seedlings), Epilobium tetragonum L. (16 seedlings), Senecio inaequidens DC. (1 seedling), Hypochaeris radicata L.(1 seedling), Betula pendula Roth (1 seedling), seedling counts include all the 35 containers) were excluded from analyses. These were probably airborne seeds that entered the greenhouse while it was opened to limit temperature elevation. The soils were watered from below, through tubes fitted to the corners of the containers. The clay balls and capillary action ensured that the moisture was spread evenly through the containers. The water supply was regular so as to keep the substrate moist, without 
soaking it. Seedling emergence survey began after the first identifiable seedling emergence on March 16,2018 . It ended on July 12,2018 , as no germination was observed for two weeks. All emergent seedlings were identified, counted and removed. Unidentifiable seedlings were transferred to separate containers and grown until identification was possible.

\section{Statistical analyses}

Floristic composition data was assessed through principal co-ordinate analyses (PсOA) using Jaccard distances. A first analysis compared species compositions in receiver sites (control plots of the field experiment), donor sites (field survey) and their seed banks. In order to assess if translocation results was either in relation to donor field floristic composition or to the seed bank composition, we performed PCOA for each of the two experiments, including: donor site (field survey), seed bank, soil translocation plots (low density and high density) and control plots. PCoA were conducted using the function 'cmdscale' from R package Vegan (Oksanen et al., 2018).

The effect of the different treatments on species richness and cover was tested using General Linear Mixed Models (GLMM) using block as a random effect. The Poisson error distribution was applied to richness indices. In these models, ratios between residuals degrees of freedom and model residuals ranged between 0.18 and 0.55 , indicating no overdispersion evidence (Osgood, 2000). For the experiment conducted at Receiver 2, total and pernicious species covers were log-transformed, while segetal and threatened were sqrt-transformed in order to improve normality and homoscedasticity of the residuals. Post-hoc comparisons were conducted using Tukey contrasts within the GLMM models. Analyses were conducted using R packages 'Ime4' (Bates et al., 2018) and 'multcomp' (Hothorn et al., 2008). 


\section{Results}

\begin{tabular}{|c|c|c|c|}
\hline & \multicolumn{2}{|c|}{ Receiver 1} & \multirow{2}{*}{$\begin{array}{c}\text { Receiver } 2 \\
\text { Donor } 2\end{array}$} \\
\hline & Donor $1 a$ & Donor $1 b$ & \\
\hline Donor site, observed in field & 81 & 44 & 40 \\
\hline Non-threatened segetals & 11 & 8 & 8 \\
\hline Threatened segetals & 7 & 8 & 7 \\
\hline Pernicious & 5 & 4 & 4 \\
\hline Donnor site seed bank & 60 & 52 & 48 \\
\hline Non-threatened segetals & 7 & 8 & 7 \\
\hline Threatened segetals & 4 & 5 & 4 \\
\hline Pernicious & 4 & 1 & 6 \\
\hline Receiving site control & \multicolumn{2}{|c|}{26} & 54 \\
\hline Non-threatened segetals & \multicolumn{2}{|c|}{3} & 5 \\
\hline Threatened segetals & \multicolumn{2}{|c|}{3} & 2 \\
\hline Pernicious & \multicolumn{2}{|c|}{2} & 7 \\
\hline Receiving site transfered & 46 & 44 & 75 \\
\hline Non-threatened segetals & 7 & 9 & 8 \\
\hline Threatened segetals & 6 & 5 & 7 \\
\hline Pernicious & 2 & 1 & 8 \\
\hline
\end{tabular}

Table 2: Number of species observed in donor site, the seed bank, the receiver site control and with topsoil translocation (low density and high density were pooled). At receiver site, the different experimental plots with the same treatment were pooled.

A total of 131 species were recorded through all the field and seed bank surveys. In both experiments, more species were found in plots with topsoil translocation than in the control (Fig. 2). The increase in species richness ranged between 39\% (Receiver 2) and 77\% (Receiver 1) (Table2). At Receiver 1, segetal species richness was the lowest in control and the highest in plots with topsoil from Donor 1a, while topsoil from Donor $1 \mathrm{~b}$ had an intermediate effect (Fig. 2a). There was no difference in the number of threatened species. At Receiver 2, species richness increased for all species groups, although the effect was larger for the plots under standard field margin control (Fig. 2b). At Receiver 2, five threatened species were translocated successfully (Table 3), whereas for Receiver 1 this was three species (Table 3). There were also several species that were present at the donor sites that did not establish at the receiver sites (Receiver 1: six species out of nine, Receiver 2: two species out of seven). However, several of those species were also not observed in the respective seed banks (receiver 1: two species, receiver 2: 1 species; Table 3). In both experiments there was no significant difference in species richness for the two soil spreading rates in any of the species groups (Fig. 2a,b). 

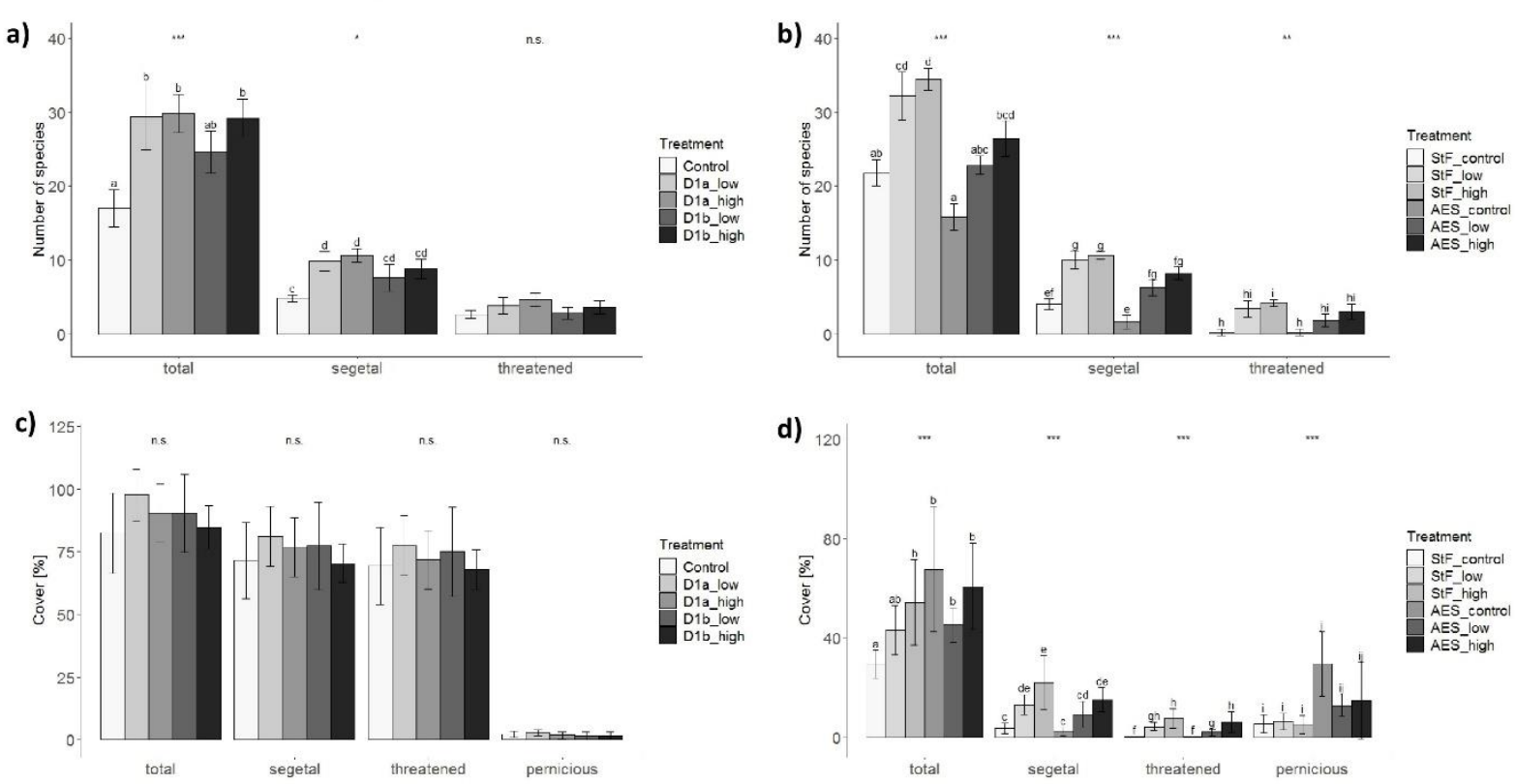

Fig.2 : Mean number of species $(a, b)$ and cover $(c, d) \pm$ SD observed in $3 \mathrm{~m}^{*} 1 \mathrm{~m}$ plots including all species (total), segetal species, threatened species and pernicious species (cover only). For Receiver 1 (a,c), the treatments were : control, topsoil translocated from Donor 1a at low and high density (respectively D1a_low and D1b_high) and topsoil translocated from Donor $1 \mathrm{~b}$ at low and high density (respectively (D1b_low and D1b_high). For Receiver $2(a, c)$, the treatments were : standard field margin control (StF_control), topsoil translocated from Donor 2 at low and high density in standard field margin (respectively StF_low and StF_high), AES-strip control (AES_control), topsoil translocated from Donor 2 at low and high density in AES-strip (respectively AES_low and AES_high). Results of ANOVA are indicated above groups of bar-charts: ${ }^{* * *}: \mathrm{P}<0.001 ;{ }^{* *}: 0.001<\mathrm{P}<0.01 ; *: 0.01<\mathrm{P}<0.05 ;$ n.s.:P>0.05. In case of significant ANOVA, significant differences between treatments are indicated by different letters.

At Receiver 1, where total plant cover in the control plots was relatively high $(82.5 \pm 15.9 \%)$, topsoil translocation did not influence cover in any of the plant groups (Fig. 2c). In contrast, at Receiver 2, covers of total, segetal and threatened species did increase under topsoil translocation treatment. At this site total cover in the controls was relatively low $(29.4 \pm 5.7 \%)$. Cover of threatened species in the AES strip was significantly higher with a higher density than with low density topsoil translocation (Fig. 2d). Pernicious species cover was not influenced significantly by the topsoil translocation treatments in either experiment (Fig. 2c,d). However, in Receiver 2 pernicious weed cover tended to decrease in the AES-strip from ca. $30 \%$ in the control to ca. $15 \%$ in translocated plots (Fig. 2 d). 
a)

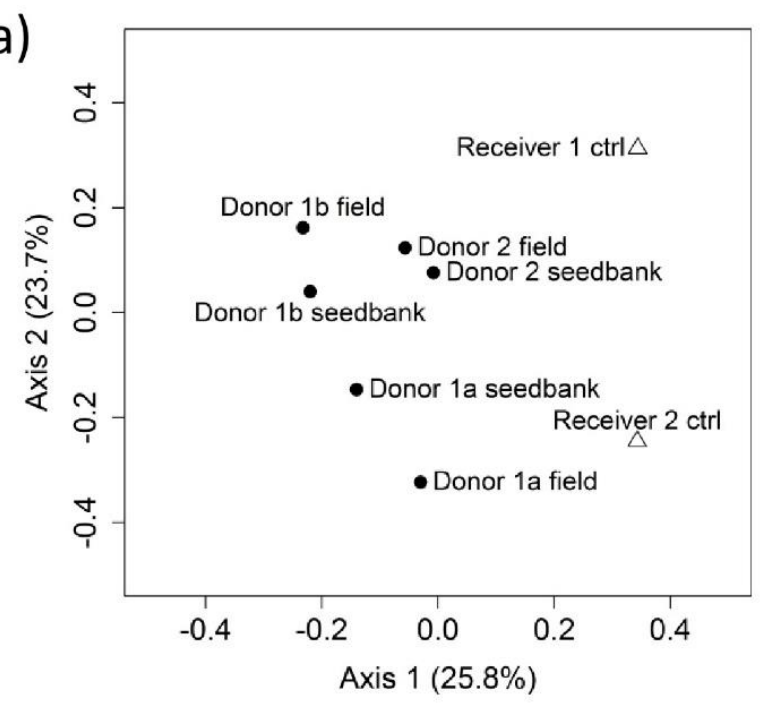

b) $\stackrel{a}{\circ}$

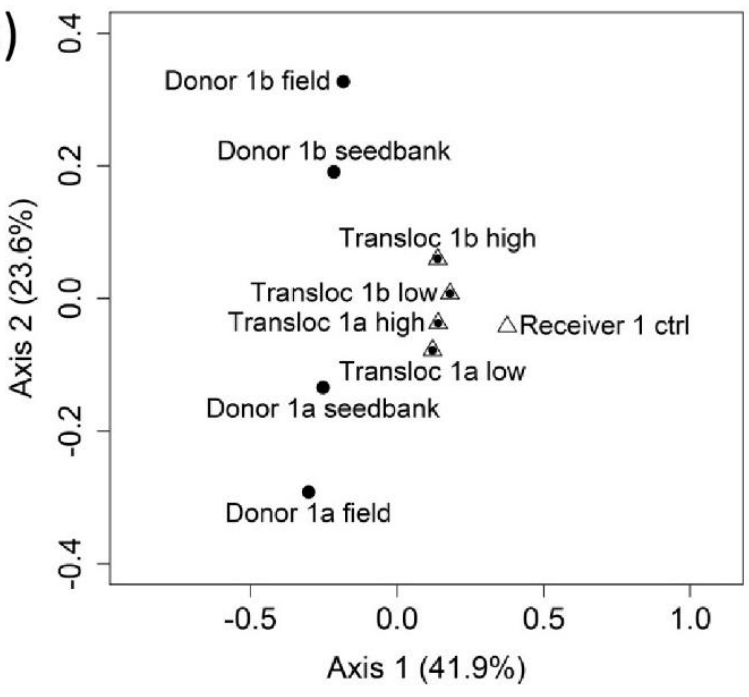

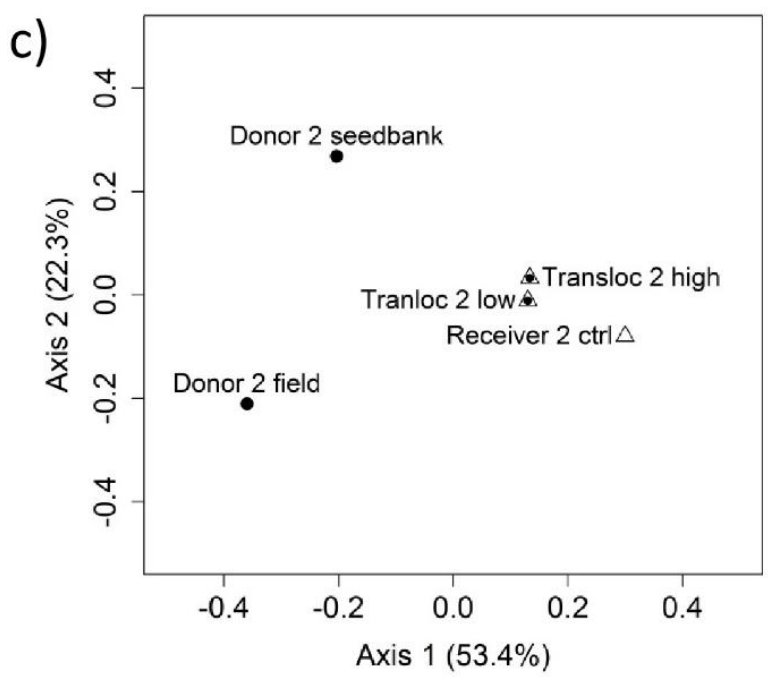

Fig.3: PCoA based on pooled species lists (Jaccard distance matrix): (a) receiver sites control (Receiver 1 ctrl and Receiver $\mathbf{2}$ ctrl), donor sites field survey (Donor 1a field, Donor $\mathbf{1 b}$ field, Donor $\mathbf{2}$ field) and donor seed banks (Donor 1a seedbank, Donor 1b seedbank, Donor 2 seedbank); (b) results of experiment 1, including receiver sites control (Receiver $1 \mathrm{ctrl}$ ), donor sites field survey (Donor 1a field, Donor $1 \mathrm{~b}$ field), donor seed banks (Donor 1a seedbank, Donor 1b seedbank) and translocated plots with low and high topsoil density (Transloc 1a low, Transloc 1a high, Transloc 1b low, Transloc $1 \mathrm{~b}$ high); (c) results of experiment 2, including receiver sites control (Receiver $\mathbf{2}$ ctrl), donor site field survey (Donor $\mathbf{2}$ field), donor seed bank (Donor $\mathbf{2}$ seedbank) and translocated plots with low and high topsoil density (Transloc 2 low, Transloc 2 high). Numbers of donor and receiver sites are those described in Table 1. Empty triangles are receiver site controls. Black dots are donor sites (seed banks and field surveys). Triangles filled with a black dot are translocated plots. 
The seed bank study showed that a large proportion of donor sites species diversity was represented in the topsoil. Numbers of recorded species were indeed comparable to donor field surveys (Table 2). Seed bank density at Donor $1 \mathrm{a}$, Donor $1 \mathrm{~b}$ and Donor 2 was $510 \pm 60$ (mean $\pm S E$ ) seeds $/ \mathrm{L}_{\text {soil, }} 197 \pm 52$ seeds $/ \mathrm{L}_{\text {soil }}$ and $137 \pm 31$ seeds $/ L_{\text {soil, }}$ respectively. Seed bank density for each species separately is provided in Appendix 1. Overall, seed bank composition was closely related to floristic composition of donor site (Fig. 3a). Indeed, mean Jaccard distance between donor site and their seed bank composition (within sites, $n=3$ ) was $0.499 \pm 0.005$ (mean $\pm S E$ ), while mean distance to other sites' seed bank (between sites, $\mathrm{N}=6$ ) was $0.605 \pm 0.010$ (mean $\pm \mathrm{SE}$ ). However the resemblance is not perfect, suggesting that floristic composition is only a rough indicator of what is contained in the seed bank (see also Table 3). In addition, seed banks from the different donor sites tended to resemble each other (mean Jaccard distance between seed banks was $0.480 \pm 0.010$ (mean \pm SE)) more than the field surveys did (mean Jaccard distance between field surveys was $0.626 \pm 0.037$ (mean \pm SE)) (Fig. 3a). Importantly, the ordinations further revealed that in both experiments, translocated plots had an intermediate position between the receiver site control and the donor site seed bank (Fig. 3b-c). Furthermore, in line with the results of species richness, spreading density had a minor influence in term of species composition. 


\begin{tabular}{|c|c|c|c|c|c|c|c|c|c|c|c|}
\hline \multirow{3}{*}{ Species } & \multicolumn{7}{|c|}{ Experiment 1} & \multicolumn{4}{|c|}{ Experiment 2} \\
\hline & \multicolumn{2}{|c|}{ Field survey } & \multicolumn{2}{|c|}{ Seed bank } & \multirow[t]{2}{*}{ Control } & \multicolumn{2}{|c|}{$\begin{array}{c}\text { Topsoil } \\
\text { translocation }\end{array}$} & \multirow{2}{*}{$\begin{array}{l}\begin{array}{l}\text { Field } \\
\text { survey }\end{array} \\
\text { Donor } 2\end{array}$} & \multirow{2}{*}{$\begin{array}{l}\text { Seed } \\
\text { bank } \\
\text { Donor } 2\end{array}$} & \multirow{2}{*}{ Control } & \multirow{2}{*}{$\begin{array}{l}\begin{array}{l}\text { Topsoil } \\
\text { translocation }\end{array} \\
\text { Donor } 2\end{array}$} \\
\hline & $\begin{array}{l}\text { Donor } \\
1 \mathrm{a}\end{array}$ & $\begin{array}{l}\text { Donor } \\
1 \mathrm{~b}\end{array}$ & $\begin{array}{l}\text { Donor } \\
1 \mathrm{a}\end{array}$ & $\begin{array}{l}\text { Donor } \\
1 \mathrm{~b}\end{array}$ & & $\begin{array}{l}\text { Donor } \\
1 a\end{array}$ & $\begin{array}{l}\text { Donor } \\
1 b\end{array}$ & & & & \\
\hline Bromus grossus Desf. Ex DC & & & & & $x$ & $x$ & $x$ & & & & \\
\hline Bromus secalinus L. & & & & & $x$ & $x$ & $x$ & & & & \\
\hline Cyanus segetum Hill & $x$ & $x$ & $x$ & $x$ & $x$ & $x$ & $x$ & $x$ & $x$ & & $\underline{\mathbf{x}}$ \\
\hline Filago lutescens Jord. & $x$ & & $x$ & & & & & & & & \\
\hline Euphorbia platyphyllos L. & & & & & & & & & & $x$ & $x$ \\
\hline Legousia hybrida (L.) Delabre & $x$ & $x$ & & $x$ & & & & $x$ & & & $\underline{\mathbf{x}}$ \\
\hline Legousia speculum-veneris (L.) Chaix & $x$ & & & & & & & & & $x$ & $\bar{x}$ \\
\hline Misopates orontium (L.) Rafin. & $x$ & $x$ & & $x$ & & $\underline{\mathbf{x}}$ & $\underline{\mathbf{x}}$ & $x$ & & & \\
\hline Papaver argemone L. & $x$ & $x$ & $x$ & & & $\underline{\mathbf{x}}$ & & $x$ & & & $\underline{\mathbf{x}}$ \\
\hline Papaver dubium L. subsp. lecoqii & & $x$ & & $x$ & & & & & & & \\
\hline Silene noctiflora $\mathrm{L}$. & & $x$ & & & & & & & & & \\
\hline Valerianella carinata Loisel. & & & & & & & & $x$ & $x$ & & \\
\hline Valerianella dentata (L.) Pollich & $x$ & $x$ & $x$ & $x$ & & $\underline{\mathbf{x}}$ & $\underline{\mathbf{x}}$ & $x$ & $x$ & & $\underline{\mathbf{x}}$ \\
\hline Valerianella rimosa Bast. & & $x$ & & & & & & $x$ & $x$ & & $\underline{\mathbf{x}}$ \\
\hline
\end{tabular}

Table 3: For each experiment, occurrence of the threatened segetal species in control, field survey and seed bank of donor site and in translocated plots (low and high density considered together). The $x$-marks indicate occurrences. Underlined bold $x$-marks indicate species observed in receiver site only in translocated plots (translocation evidences). Grey fonts indicate species that were absent at receiver site despite their presence at donor site (translocation failures). 


\section{Discussion}

Our experiments demonstrated that topsoil translocation can be an effective tool for recovering speciesrich segetal flora within arable fields under low intensity cultivation. Indeed, in most treatments we observed increased species richness in translocated plots compared to the controls, largely irrespective of the donor site and spreading density. In the fertile site (Receiver 1), we only documented increases in species richness, while in the less fertile site (Receiver 2) both richness and cover increased in tandem. In both experiments, we found that the plots with translocated soil were intermediate to the untreated controls and the donor site seed bank in terms of their species composition. This highlights that topsoil translocation was effective in transforming the vegetation, but that restoration success was not complete.

Overall, topsoil translocation led to substantial gains in species richness (40-70\%). Furthermore, at both sites we observed the successful establishment of threatened segetal species in translocated plots; $33 \%$ and $70 \%$ of the threatened species that could potentially have been introduced with the topsoil for Receiver 2 and 1 respectively (Table 3). However, not all threatened species that were present at the donor sites were translocated successfully and this can be for several reasons. For instance, some species were not recorded in the seed bank, such as S. noctiflora at Donor $1 \mathrm{~b}$, and Misopates orontium (L.) Rafin. at Donor 1a, which suggest that they had not yet build up a persistent seedbank, or that it was not dense enough to be detected in a sample. Alternatively, for other species the environmental conditions at receiver site may have hampered the establishment. In our study, that was probably the case for Filago lutescens Jord., which is a species from gravelly soils (Rich, 1999), present at Donor 1a, while the deeper soil at Receiver 1 does not feature this type of habitat. Also Valerianella carinata Loisel. may have been hampered by the poor soil drainage at Receiver 2 , as it is more typical of drier places (Pinke et al., 2011). Interestingly, we also found species that were absent from seed bank of the donor site but that were found in translocated plots, e.g. Legousia hybrida (L.) Delabre in Receiver 2 (Table 3). Absence of seeds in the seed bank survey may, therefore, be a reason for translocation failure, but that does not have to be the case.

In one experiment (Receiver 1), we found that topsoil translocation only increased the species richness and not the plant cover in the different groups. However, in the other experiment (Receiver 2), both richness and cover increased in tandem in response to topsoil translocation. The two experimental sites differed substantially in their local conditions, with Receiver 1 being more fertile. This was further corroborated by the total plant cover observed in the control plots in both experiments (Fig. 2a,b). Indeed in Receiver 1, two threatened segetal species, i.e. C. segetum and B. grossus, were dominant in control plots. These are large-statured species that are highly-competitive (Piqueray et al., 2018; 
Thompson and Woodward, 1994). This suggests that high resident plant community cover and high fertility may limit the extent to which new species can be introduced by topsoil translocation. Interestingly, pernicious weed cover tended to decrease in AES-strip from ca. $30 \%$ in control to ca. $15 \%$ in translocated plots, albeit non-significantly. This suggests that topsoil translocation may have promoted the target flora at the expense of the pernicious weeds, potentially due to co-introduction of soil-borne antagonists of these weeds with the topsoil (Kardol et al., 2006; Reynolds et al., 2003; Wubs et al., 2016). Together, these results suggest an important role for competition from the established vegetation on the abundance of the translocated species. However, even under these competitive conditions, topsoil translocation was effective in introducing these species, albeit in small populations.

In our study, species composition in topsoil treated plots was more closely related to the seed bank of the donor site than to standing vegetation of the donor site. Most arable plants do form a seed bank, but some may be systematically under-represented, notably the species with larger seeds that tend to be less numerous and less persistent in the soil (Gaba et al., 2017). Indeed, seed banks from the different donor sites tended to be more closely related than the sites' species composition themselves (Fig. 3a), suggesting that a common set of species was present in all seed banks. Seedling emergence in the seed bank study could have been increased through washing and seed concentration, as suggested by Ter Heerdt et al. (1996). However, our main objective was to predict floristic patterns observed in the translocation experiments as a prospective assessment to be used in future restoration projects, rather than fully describe the seed bank composition. Therefore, we chose to replicate, as far as possible, the conditions that were used in the field study. Donor sites $1 \mathrm{a}$ and $1 \mathrm{~b}$ were chosen as separate donor sites for Receiver 1 because monitoring revealed them as distinct in their species composition (Fig. 3a). The intention was that this would increase overall plant diversity in Receiver 1, but likely due to the species filter imposed by the seedbank the effect of donor complementarity on species richness was lower than expected. We, therefore, recommend that the selection of donor sites is made based on seed bank analyses, rather than on field surveys.

In general, the soil spreading density had no systematic effect on species richness and cover in our study. The only exception was the small, but significant, increase in threatened species cover in AES strip of Receiver 2 from low to high spreading density treatments (Fig. 2d). This difference may have been caused by differences in seed density among the donor soils. The Donor 2 site had the lowest amount of seeds in the seed bank (137 seeds $/ \mathrm{L}_{\text {soil }}$ ), while the densities for Donor $1 \mathrm{a}$ (510 seeds $/ \mathrm{L}_{\text {soil }}$ ) and $1 \mathrm{~b}$ (197 seeds $\left./ L_{\text {soil }}\right)$ were higher. However, in response to the intermediate seed density of Donor $1 \mathrm{~b}$ a high spreading density was necessary to obtain a significant difference in total species richness compared to control (Fig. 1a). Together this suggests there is a minimum of viable seeds that needs to be present in the topsoil for successful restoration, but that this threshold is typically exceeded by the seed densities 
present within these systems. Although further studies are needed to refine our result, we argue based on the case of Donor $1 \mathrm{~b}$ that a low density spreading $\left(\approx \mathrm{ca} .500\right.$ seeds $\left./ \mathrm{m}^{2}\right)$ can be considered a first approximation to be used in further projects.

Several key questions remain open for further research. Importantly, the long-term fate of the translocated species needs to be documented. Is this a restoration measure that only needs to be implemented once during initial site preparation, or should it be repeated? Being mostly annuals, species that were translocated successfully also had to complete their life-cycle and produce seed in order to initiate the build-up of a seed bank at the receiver site. Next, can the small-size plots in the experiment act as initial stepping-stones from which the remainder of the fields can be colonized without further intervention? This remains an open question as many of the segetal species are known to have poor dispersal abilities (Bischoff, 2005; Mayer and Albrecht, 2008). Nevertheless, Lang et al. (2018) showed that dispersal of arable plants due farming practice (e.g. tillage and harvesting) may nonetheless reach several meters per year. If whole fields need to be treated with topsoil, or the treatments need to be repeated, then our method may require substantial amounts of soil. In that case, it will be critical to investigate the rates at which soil can be harvested sustainably from donor sites, for instance based on models used for harvested populations dynamics (Caswell, 2001), as applied in fisheries and forestry. However, we expect that our small-scale experimental plots will act as a starting point for the restoration of the whole field and only single time interventions are needed to kick-start the restoration.

\section{Conclusion}

Our study demonstrated that topsoil translocation can be an effective tool to restore species-rich arable fields, including rare segetal species. We found that even in closed vegetation, topsoil translocation could still increase species richness. However, relatively larger effects were found in the infertile Receiver 2 site where the canopy was not closed; suggesting that competition from established vegetation is an important factor influencing restoration success. We also showed that a prior survey of the seed bank composition of potential donor sites provides a more realistic picture of vegetation that is to be expected upon soil translocation. Overall, topsoil translocation can be an effective tool to conserve the specialized segetal flora of old agricultural landscapes, but investigations of the long-term consequences of the treatments and the impacts of soil harvesting on donor sites are now needed. 


\section{Acknowledgment}

The authors cheerily thank Céleste Quaghebeur for initiating this study (farmer contacting and topsoil collection) during her student internship. The authors also thank the farmers who participated to the study and the Walloon administration (DGO3-DNF) for their authorization to work in nature reserves. Natagriwal is a not-for-profit association funded by the Walloon Government. ERJW was funded by a NWO-RUBICON grant (Netherlands Organization for Scientific Research, contract no. 019.181EN.01)

\section{References}

Albrecht, H., 2005. Development of arable weed seedbanks during the 6 years after the change from conventional to organic farming. Weed Res. 45, 339-350. https://doi.org/10.1111/j.13653180.2005.00472.x

Albrecht, H., Cambecèdes, J., Lang, M., Wagner, M., 2016. Management options for the conservation of rare arable plants in Europe. Bot. Lett. 163, 389-415. https://doi.org/10.1080/23818107.2016.1237886

Bartha, S., Szentes, S., Horváth, A., Házi, J., Zimmermann, Z., Molnár, C., Dancza, I., Margóczi, K., Pál, R.W., Purger, D., Schmidt, D., Óvári, M., Komoly, C., Sutyinszki, Z., Szabó, G., Csathó, A.I., Juhász, M., Penksza, K., Molnár, Z., 2014. Impact of mid-successional dominant species on the diversity and progress of succession in regenerating temperate grasslands. Appl. Veg. Sci. 17, 201-213. https://doi.org/10.1111/avsc.12066

Bates, D., Maechler, M., Bolker, B., Walker, S., Christensen, R.H.B., Singmann, H., et al, 2018. Package "Ime4." R Found. Stat. Comput. Vienna Austria. https://doi.org/10.18637/jss.v067.i01

Bischoff, A., 2005. Analysis of weed dispersal to predict chances of re-colonisation. Agric. Ecosyst. Environ. 106, 377-387. https://doi.org/10.1016/j.agee.2004.09.006

Bock, L., Legrain, X., Veron, P., Bracke, C., Bah, B., Lejeune, P., 2008. Carte Numérique des Sols de Wallonie - version 1.2. Convention financée par la Région Wallonne (DGA, MRW). Unité SolEcologie-Territoire (Laboratoire de Géopédologie) et Unité de Gestion des Ressources forestières et des Milieux naturels, Faculté universitaire des Sciences agronomiques de Gembloux, Gembloux, Belgique.

Buisson, E., Jaunatre, R., Römermann, C., Bulot, A., Dutoit, T., 2018. Species transfer via topsoil translocation: lessons from two large Mediterranean restoration projects. Restor. Ecol. 26, 179188. https://doi.org/10.1111/rec.12682

Cambecèdes, J., Largier, A., Lombard, G., 2012. Plan national d'actions aménagements en faveur des plantes messicoles. Conservatoire botanique national des Pyrénées et de Midi-Pyrénées Fédération des Conservatoires botaniques nationaux - Ministère de l'Écologie, du Développement durable et de l'Énergie.

Caswell, H., 2001. Matrix population models: construction, analysis and interpretation, 2 nd ed. Sinauer Associates, Sunderland, Mass.

Cramer, V.A., Hobbs, R.J., Standish, R.J., 2008. What's new about old fields? Land abandonment and ecosystem assembly. Trends Ecol. Evol. 23, 104-112. https://doi.org/10.1016/j.tree.2007.10.005

Ferreira, M.C., Walter, B.M.T., Vieira, D.L.M., 2015. Topsoil translocation for Brazilian savanna restoration: Propagation of herbs, shrubs, and trees. Restor. Ecol. 23, 723-728. https://doi.org/10.1111/rec.12252

Fried, G., Petit, S., Dessaint, F., Reboud, X., 2009. Arable weed decline in Northern France: Crop edges as refugia for weed conservation? Biol. Conserv. 142, 238-243. https://doi.org/10.1016/j.biocon.2008.09.029 
Gaba, S., Perronne, R., Fried, G., Gardarin, A., Bretagnolle, F., Biju-Duval, L., Colbach, N., Cordeau, S., Fernández-Aparicio, M., Gauvrit, C., Gibot-Leclerc, S., Guillemin, J.P., Moreau, D., Munier-Jolain, N., Strbik, F., Reboud, X., 2017. Response and effect traits of arable weeds in agro-ecosystems: a review of current knowledge. Weed Res. 57, 123-147. https://doi.org/10.1111/wre.12245

Haaland, C., Naisbit, R.E., Bersier, L.F., 2011. Sown wildflower strips for insect conservation: A review. Insect Conserv. Divers. 4, 60-80. https://doi.org/10.1111/j.1752-4598.2010.00098.x

Hall, S.L., Barton, C.D., Baskin, C.C., 2010. Topsoil Seed Bank of an Oak-Hickory Forest in Eastern Kentucky as a Restoration Tool on Surface Mines. Restor. Ecol. 18, 834-842. https://doi.org/10.1111/j.1526-100X.2008.00509.x

Harris, J., 2009. Soil Microbial Communities and Restoration Ecology: Facilitators or Followers? Science 325, 573-574. https://doi.org/10.1126/science.1172975

Hicks, D.M., Ouvrard, P., Baldock, K.C.R., Baude, M., Goddard, M.A., Kunin, W.E., Mitschunas, N., Memmott, J., Morse, H., Nikolitsi, M., Osgathorpe, L.M., Potts, S.G., Robertson, K.M., Scott, A. V., Sinclair, F., Westbury, D.B., Stone, G.N., 2016. Food for pollinators: Quantifying the nectar and pollen resources of urban flower meadows. PLoS ONE 11, e0158117. https://doi.org/10.1371/journal.pone.0158117

Hofmeister, H., Garve, E., 1998. Lebensraum Acker. Parey Buch Verlag, Berlin, Deutschland.

Hothorn, T., Bretz, F., Westfall, P., 2008. Simultaneous inference in general parametric models. Biom. J. https://doi.org/10.1002/bimj.200810425

Kardol, P., Martijn Bezemer, T., van der Putten, W.H., 2006. Temporal variation in plant-soil feedback controls succession: Plant-soil feedback controls succession. Ecol. Lett. 9, 1080-1088. https://doi.org/10.1111/j.1461-0248.2006.00953.x

Keller, M., Kollmann, J., Edwards, P.J., 2000. Genetic introgression from distant provenances reduces fitness in local weed populations. J. Appl. Ecol. 37, 647-659. https://doi.org/10.1046/j.13652664.2000.00517.x

Lambinon, J., Delvosalle, L., Duvigneaud, J., 2004. Nouvelle flore de la Belgique, du G.-D. de Luxembourg, du Nord de la France et des régions voisines, 5th ed. Jardin botanique national de Belgique, Meise.

Lang, M., Prestele, J., Fischer, C., Kollmann, J., Albrecht, H., 2016. Reintroduction of rare arable plants by seed transfer. What are the optimal sowing rates? Ecol. Evol. 6, 5506-5516. https://doi.org/10.1002/ece3.2303

Lang, M., Prestele, J., Wiesinger, K., Kollmann, J., Albrecht, H., 2018. Reintroduction of rare arable plants : seed production, soil seed banks, and dispersal 3 years after sowing. Restor. Ecol. In Press. https://doi.org/10.1111/rec.12696

Le Stradic, S., Séleck, M., Lebrun, J., Boisson, S., Handjila, G., Faucon, M.P., Enk, T., Mahy, G., 2016. Comparison of translocation methods to conserve metallophyte communities in the Southeastern D.R. Congo. Environ. Sci. Pollut. Res. 23, 13681-13692. https://doi.org/10.1007/s11356-015-5548-6

Lemoine, C., Sérusiaux, E., Mahy, G., Piqueray, J., 2018. Agro-environmental scheme for segetal plant conservation in Wallonia (Belgium): an assessment in conventional and organic fields. Biotechnol. Agron. Soc. Environ. 22, 35-44.

Marshall, E.J.P., Brown, V.K., Boatman, N.D., Lutman, P.J.W., Squire, G.R., Ward, L.K., 2003. The role of weeds in supporting biological diversity within crop fields. Weed Res. https://doi.org/10.1046/j.1365-3180.2003.00326.x

Mayer, F., Albrecht, H., 2008. Dispersal Strategies. Are They Responsible for Species Success in Arable Ecosystems?, in: Perspectives for Agroecosystem Management: Balancing Environmental and Socio-Economic Demands. Elsevier, Amsterdam / Oxford, pp. 257-278. https://doi.org/10.1016/B978-044451905-4.50010-6

Meyer, S., Wesche, K., Metzner, J., Van Elsen, T., Leuschner, C., 2010. Are current agri-environment schemes suitable for long-term conservation of arable plants? - A short review of different conservation strategies from Germany and brief remarks on the new project "100 fields for diversity." Asp. Appl. Biol. 100, 287-294. 
Nicholls, C., Altieri, M., 2004. Designing species-rich, pest-suppressive agroecosystems through habitat management. Agronomy 49-62. https://doi.org/2018/EE/C8EE01365A

Nicholls, C.I., Altieri, M.A., 2013. Plant biodiversity enhances bees and other insect pollinators in agroecosystems. A review. Agron. Sustain. Dev. 33, 257-274. https://doi.org/10.1007/s13593012-0092-y

Oksanen, A.J., Blanchet, F.G., Kindt, R., Legen-, P., Minchin, P.R., Hara, R.B.O., Simpson, G.L., Soly-, P., Stevens, M.H.H., Wagner, H., 2018. Package 'vegan' version 2.5-2. URL Httpscranr-Proj. Httpsgithubcomvegandevsvegan. https://doi.org/ISBN 0-387-95457-0

Osgood, D.W., 2000. Poisson-based regression analysis of aggregate crime rates. J. Quant. Criminol. 16, 21-43. https://doi.org/10.1023/A:1007521427059

Pinke, G., Király, G., Barina, Z., Mesterházy, A., Balogh, L., Csiky, J., Schmotzer, A., MolnáR, A. V., Pál, R.W., 2011. Assessment of endangered synanthropic plants of hungary with special attention to arable weeds. Plant Biosyst. 145, 426-435. https://doi.org/10.1080/11263504.2011.563534

Piqueray, J., Gilliaux, V., Gaillard, T., Mahy, G., Delescaille, L., 2018. Uncleaned crop seed sowing as a tool to conserve Bromus grossus and restore species - rich arable - dependent plant communities. Conserv. Evid. 15, 26-31.

Reynolds, H.L., Packer, A., Bever, J.D., Clay, K., 2003. Grassroots ecology: plant-microbe-soil interactions as drivers of plant community structure and dynamics. Ecology 84, 2281-2291. https://doi.org/10.1890/02-0298

Rich, T.C.G., 1999. Conservation of Britain's biodiversity: Filago lutescens Jordan (Asteraceae), Redtipped cudweed. Watsonia 22, 251-260.

Rotchés-Ribalta, R., Blanco-Moreno, J.M., Armengot, L., Sans, F.X., 2016. Responses of rare and common segetal species to wheat competition and fertiliser type and dose. Weed Res. 56, 114-123. https://doi.org/10.1111/wre.12191

Saatkamp, A., Affre, L., Dutoit, T., Poschlod, P., 2011. Germination traits explain soil seed persistence across species: The case of Mediterranean annual plants in cereal fields. Ann. Bot. 107, 415-426. https://doi.org/10.1093/aob/mcq255

Saintenoy-Simon, J., Barbier, Y., Delescaille, L.-M., Dufrêne, M., Gathoye, J.-L., Verté, P., 2006. Première liste des espèces rares, menacées et protégées de la Région Wallonne (Ptéridophytes et Spermatophytes] [WWW Document]. URL http://biodiversite.wallonie.be/fr/liste-destaxons.html?IDD=1755\&IDC=3076

Stoate, C., Boatman, N.D., Borralho, R.J., Carvalho, C.R., de Snoo, G.R., Eden, P., 2001. Ecological impacts of arable intensification in Europe. J. Environ. Manage. 63, 337-365. https://doi.org/10.1006/jema.2001.0473

Storkey, J., Meyer, S., Still, K.S., Leuschner, C., 2012. The impact of agricultural intensification and landuse change on the European arable flora. Proc. R. Soc. B Biol. Sci. 279, 1421-1429. https://doi.org/10.1098/rspb.2011.1686

Storkey, J., Westbury, D.B., 2007. Managing arable weeds for biodiversity. Pest Manag. Sci. https://doi.org/10.1002/ps.1375

Ter Heerdt, G.N.J., Verweij, G.L., Bekker, R.M., Bakker, J.P., 1996. An Improved Method for Seed-Bank Analysis: Seedling Emergence After Removing the Soil by Sieving. Funct. Ecol. 10, 144. https://doi.org/10.2307/2390273

Thompson, G.B., Woodward, F.I., 1994. Some influences of CO2 enrichment, nitrogen nutrition and competition on grain yield and quality in spring wheat and barley. J. Exp. Bot. 45, 937-942. https://doi.org/10.1093/jxb/45.7.937

Vécrin, M.P., Muller, S., 2003. Top-soil translocation as a technique in the re-creation of species-rich meadows. Appl. Veg. Sci. 6, 271-278. https://doi.org/10.1111/j.1654-109X.2003.tb00588.x

Wagner, M., Bullock, J.M., Hulmes, L., Hulmes, S., Pywell, R.F., 2017. Cereal density and N-fertiliser effects on the flora and biodiversity value of arable headlands. Biodivers. Conserv. 26, 85-102. https://doi.org/10.1007/s10531-016-1225-4 
Wilson, J.D., Morris, A.J., Arroyo, B.E., Clark, S.C., Bradbury, R.B., 1999. A review of the abundance and diversity of invertebrate and plant foods of granivorous birds in northern Europe in relation to agricultural change. Agric. Ecosyst. Environ. https://doi.org/10.1016/S0167-8809(99)00064-X

Wubs, E.R.J., van der Putten, W.H., Bosch, M., Bezemer, T.M., 2016. Soil inoculation steers restoration of terrestrial ecosystems. Nat. Plants 2. https://doi.org/10.1038/nplants.2016.107

Wubs, E.R.J., van der Putten, W.H., Mortimer, S.R., Korthals, G.W., Duyts, H., Wagenaar, R., Bezemer, T.M., 2019. Single introductions of soil biota and plants generate long-term legacies in soil and plant community assembly. Ecol. Lett. ele.13271. https://doi.org/10.1111/ele.13271 


\section{Appendix}

Appendix 1: Seed bank surveys of donor sites. Mean and SD ( $N=10$ for each donor site) in seeds/ $L_{\text {topsoil. }}$

\begin{tabular}{|c|c|c|c|c|c|c|}
\hline \multirow{2}{*}{ Species } & \multicolumn{2}{|c|}{ Donor 1a } & \multicolumn{2}{|c|}{ Donor 1b } & \multicolumn{2}{|c|}{ Donor 2} \\
\hline & Mean & SD & Mean & SD & Mean & SD \\
\hline Aethusa cynapium L. & 0.5 & 1.2 & 0.4 & 0.8 & 0.2 & 0.6 \\
\hline Agrostis gigantea Roth & 0.0 & 0.0 & 0.2 & 0.6 & 0.2 & 0.6 \\
\hline Alopecurus myosuroides Huds. & 6.0 & 3.5 & 0.0 & 0.0 & 0.4 & 0.8 \\
\hline Anagallis arvensis L. subsp. arvensis & 15.8 & 9.2 & 19.3 & 8.0 & 2.4 & 3.0 \\
\hline Anthemis arvensis $\mathrm{L}$. & 62.0 & 15.7 & 1.1 & 2.3 & 3.8 & 2.5 \\
\hline Aphanes arvensis L. & 90.9 & 18.0 & 8.7 & 3.4 & 11.3 & 5.1 \\
\hline Arabidopsis thaliana (L.) Heynh. & 105.3 & 19.8 & 27.1 & 11.3 & 3.6 & 5.4 \\
\hline Arenaria serpyllifolia L. & 6.9 & 5.0 & 0.7 & 1.8 & 0.7 & 0.9 \\
\hline Avena sativa $\mathrm{L}$. & 0.0 & 0.0 & 0.4 & 0.8 & 0.0 & 0.0 \\
\hline Barbarea intermedia Boreau & 0.7 & 1.3 & 0.0 & 0.0 & 0.0 & 0.0 \\
\hline Capsella bursa-pastoris (L.) Med. & 1.3 & 1.5 & 4.4 & 2.6 & 1.6 & 1.3 \\
\hline Cardamine hirsuta L. & 0.0 & 0.0 & 0.5 & 1.7 & 0.2 & 0.6 \\
\hline Cerastium fontanum Baumg. & 0.4 & 0.8 & 0.0 & 0.0 & 0.0 & 0.0 \\
\hline Cerastium glomeratum Thuill. & 11.6 & 6.1 & 0.4 & 0.8 & 0.2 & 0.6 \\
\hline Chaenorrhinum minus (L.) Lange & 0.9 & 1.8 & 0.5 & 0.9 & 0.0 & 0.0 \\
\hline Chenopodium album L. & 2.5 & 1.8 & 13.6 & 6.3 & 3.3 & 2.8 \\
\hline Chenopodium polyspermum L. & 0.2 & 0.6 & 0.0 & 0.0 & 0.0 & 0.0 \\
\hline Cirsium vulgare (Savi) Ten. & 0.5 & 1.2 & 0.0 & 0.0 & 0.0 & 0.0 \\
\hline Crepis capillaris (L.) Wallr. & 0.0 & 0.0 & 0.0 & 0.0 & 0.2 & 0.6 \\
\hline Cyanus segetum Hill & 0.4 & 0.8 & 1.3 & 1.2 & 0.4 & 0.8 \\
\hline Elymus repens (L.) Gould. & 0.2 & 0.6 & 0.0 & 0.0 & 0.2 & 0.6 \\
\hline Erophila verna (L.) Chevall. & 1.6 & 1.3 & 0.2 & 0.6 & 0.0 & 0.0 \\
\hline Euphorbia exigua L. & 0.4 & 0.8 & 0.0 & 0.0 & 0.0 & 0.0 \\
\hline Euphorbia helioscopia L. & 0.0 & 0.0 & 0.5 & 0.9 & 0.2 & 0.6 \\
\hline Fallopia convolvulus (L.) A. Löve & 0.2 & 0.6 & 0.0 & 0.0 & 0.5 & 0.9 \\
\hline Filago lutescens Jord. & 2.5 & 2.1 & 0.0 & 0.0 & 0.0 & 0.0 \\
\hline Fumaria officinalis L. & 0.2 & 0.6 & 1.8 & 1.2 & 0.0 & 0.0 \\
\hline Galium aparine L. & 0.2 & 0.6 & 0.0 & 0.0 & 0.2 & 0.6 \\
\hline Geranium pusillum L. & 0.9 & 1.0 & 0.2 & 0.6 & 0.5 & 0.9 \\
\hline Gnaphalium uliginosum L. & 0.2 & 0.6 & 0.0 & 0.0 & 0.0 & 0.0 \\
\hline Holcus lanatus L. & 0.0 & 0.0 & 0.2 & 0.6 & 0.0 & 0.0 \\
\hline Juncus bufonius L. & 0.7 & 0.9 & 0.5 & 1.2 & 0.4 & 0.8 \\
\hline Kickxia elatine (L.) Dum. & 0.4 & 0.8 & 1.1 & 1.8 & 0.0 & 0.0 \\
\hline Lamium amplexicaule L. & 0.2 & 0.6 & 1.1 & 1.3 & 0.7 & 0.9 \\
\hline Lamium purpureum L. & 0.4 & 0.8 & 1.1 & 0.9 & 0.9 & 1.0 \\
\hline Lapsana communis L. & 0.7 & 1.3 & 1.1 & 1.3 & 0.9 & 1.0 \\
\hline Legousia hybrida (L.) Delabre & 0.0 & 0.0 & 0.4 & 1.1 & 0.0 & 0.0 \\
\hline Lepidium campestre (L.) R. Brown & 0.4 & 1.1 & 0.0 & 0.0 & 0.0 & 0.0 \\
\hline Linaria vulgaris Mill. & 0.4 & 1.1 & 0.4 & 0.8 & 0.0 & 0.0 \\
\hline Lolium sp. & 0.0 & 0.0 & 0.2 & 0.6 & 0.9 & 1.0 \\
\hline
\end{tabular}




\begin{tabular}{|c|c|c|c|c|c|c|}
\hline \multirow{2}{*}{ Species } & \multicolumn{2}{|c|}{ Donor 1a } & \multicolumn{2}{|c|}{ Donor $1 b$} & \multicolumn{2}{|c|}{ Donor 2} \\
\hline & Mean & SD & Mean & SD & Mean & SD \\
\hline Matricaria recutita $\mathrm{L}$. & 1.6 & 2.6 & 0.0 & 0.0 & 1.5 & 1.4 \\
\hline Misopates orontium (L.) Rafin. & 0.0 & 0.0 & 0.5 & 0.9 & 0.0 & 0.0 \\
\hline Myosotis arvensis (L.) Hill & 7.6 & 2.9 & 0.0 & 0.0 & 0.4 & 1.1 \\
\hline Papaver argemone L. & 0.5 & 0.9 & 0.0 & 0.0 & 0.0 & 0.0 \\
\hline Papaver dubium L. subsp. dubium & 21.6 & 8.0 & 1.1 & 1.8 & 0.2 & 0.6 \\
\hline Papaver dubium L. subsp. lecoqii & 0.0 & 0.0 & 2.0 & 1.8 & 0.0 & 0.0 \\
\hline Papaver rhoeas $\mathrm{L}$. & 18.4 & 3.9 & 7.6 & 4.4 & 25.6 & 3.8 \\
\hline Perrenial grasses & 13.8 & 7.8 & 3.1 & 2.7 & 0.7 & 0.9 \\
\hline Phleum sp. & 0.2 & 0.6 & 0.5 & 1.2 & 0.0 & 0.0 \\
\hline Plantago major L. & 0.4 & 0.8 & 1.1 & 1.3 & 5.1 & 3.4 \\
\hline Poa annua $\mathrm{L}$. & 6.7 & 4.8 & 30.5 & 9.4 & 4.7 & 2.5 \\
\hline Polygonum aviculare L. & 10.9 & 3.4 & 16.5 & 7.2 & 0.9 & 1.5 \\
\hline Polygonum persicaria L. & 0.0 & 0.0 & 0.2 & 0.6 & 0.0 & 0.0 \\
\hline Rumex crispus L. & 0.0 & 0.0 & 0.0 & 0.0 & 0.4 & 1.1 \\
\hline Rumex obtusifolius L. & 0.0 & 0.0 & 0.0 & 0.0 & 20.4 & 7.0 \\
\hline Scleranthus annuus L. & 1.6 & 1.6 & 0.0 & 0.0 & 0.0 & 0.0 \\
\hline Sherardia arvensis L. & 0.0 & 0.0 & 2.5 & 1.8 & 0.0 & 0.0 \\
\hline Silene latifolia Poiret subsp. alba & 0.0 & 0.0 & 0.2 & 0.6 & 0.0 & 0.0 \\
\hline Sinapis arvensis L. & 0.0 & 0.0 & 0.0 & 0.0 & 0.4 & 1.1 \\
\hline Sisymbrium officinale (L.) Scop. & 0.5 & 1.2 & 0.0 & 0.0 & 0.0 & 0.0 \\
\hline Sonchus arvensis L. & 0.2 & 0.6 & 0.0 & 0.0 & 0.0 & 0.0 \\
\hline Sonchus asper (L.) Hill & 0.0 & 0.0 & 6.2 & 4.8 & 0.2 & 0.6 \\
\hline Stellaria media (L.) Vill. & 0.5 & 1.2 & 1.3 & 1.2 & 1.3 & 1.2 \\
\hline Thlaspi arvense L. & 0.4 & 1.1 & 2.7 & 2.5 & 3.5 & 3.5 \\
\hline Trifolium arvense $\mathrm{L}$. & 0.2 & 0.6 & 0.0 & 0.0 & 0.0 & 0.0 \\
\hline Trifolium dubium Sibth. & 0.2 & 0.6 & 0.2 & 0.6 & 0.0 & 0.0 \\
\hline Trifolium hybridum L. & 0.0 & 0.0 & 0.2 & 0.6 & 0.0 & 0.0 \\
\hline Trifolium repens $\mathrm{L}$. & 0.4 & 1.1 & 0.2 & 0.6 & 2.2 & 1.4 \\
\hline Tripleurospermum inodorum Sch. Bip. & 19.5 & 7.9 & 13.5 & 6.8 & 4.0 & 3.3 \\
\hline Valerianella carinata Loisel. & 0.0 & 0.0 & 0.0 & 0.0 & 2.9 & 2.9 \\
\hline Valerianella dentata (L.) Pollich & 16.7 & 7.6 & 0.4 & 0.8 & 5.5 & 3.4 \\
\hline Valerianella locusta (L.) Laterr. & 3.1 & 3.2 & 0.0 & 0.0 & 0.9 & 1.8 \\
\hline Valerianella rimosa Bast. & 0.0 & 0.0 & 0.0 & 0.0 & 0.5 & 1.2 \\
\hline Veronica arvensis L. & 31.3 & 7.4 & 5.5 & 3.7 & 5.6 & 3.4 \\
\hline Veronica hederifolia L. & 10.5 & 5.6 & 1.6 & 2.0 & 1.5 & 1.4 \\
\hline Veronica persica Poiret & 2.5 & 2.6 & 3.1 & 4.0 & 8.2 & 8.2 \\
\hline Vicia hirsuta (L.) S.F. Gray & 5.5 & 1.7 & 3.6 & 2.1 & 6.0 & 4.5 \\
\hline Vicia sativa $\mathrm{L}$. & 0.2 & 0.6 & 0.4 & 0.8 & 0.0 & 0.0 \\
\hline Vicia tetrasperma (L.) Schreb. & 0.2 & 0.6 & 0.7 & 1.3 & 0.0 & 0.0 \\
\hline Viola arvensis Murray & 14.7 & 9.6 & 3.5 & 3.7 & 0.9 & 1.5 \\
\hline Vulpia myuros (L.) C.C. Gmel. & 4.5 & 1.5 & 0.0 & 0.0 & 0.0 & 0.0 \\
\hline Total & 510 & 60 & 197 & 52 & 137 & 31 \\
\hline
\end{tabular}

